\title{
REALITAS SOSIAL DALAM NOVEL LONTARA RINDU KARYA S. GEGGE MAPPANGEWA
}

\author{
Ayu Safitri ${ }^{1}$, Irianto Ibrahim ${ }^{2}$ \\ Pbsi.fkip.uho@gmail.com
}

\begin{abstract}
1,2 Jurusan Pendidikan Bahasa dan Sastra Indonesia, Fakultas Keguruan dan Ilmu Pendidikan, Universitas Halu Oleo Kampus Hijau Bumi Tridharma Anduonuhu, Kendari, Indonesia
\end{abstract}

\begin{abstract}
ABSTRAK
Penelitian ini dilatarbelakangi oleh pertimbangan bahwa novel Lontara Rindu kary S. Gegge Mappangewa sangat kental menampilkan realitas sosial yang ada dalam masyarakat. Masalah dalam penelitian ini adalah bagaimanakah realitas sosial dalam novel Lontara Rindu karya S. Gegge Mappangewa?. Penelitian ini bertujuan untuk mendeskripsikan realitas sosial yang terdapat dalam novel Lontara Rindu karya S. Gegge Mappangewa. Metode yang digunakan dalam penelitian ini adalah metode deskriptif kualitatif. Penelitian ini termasuk jenis penelitian kepustakaan. Data dalam penelitian ini adalah data tertulis yang berupa teks novel yang mencangkup realitas sosial yang ada dalam novel. sumber data penelitian ini adalah novel Lontara Rindu karya S. Gegge Mappangewa terbitan Republika, Jakarta selatan, cetakan pertama tahun 2012 dan terdiri dari 343 halaman. Teknik pengumpulan data yang digunakan teknik baca catat. Data dalam penelitian ini dianalisis dengan menggunakan pendekatan sosiologi karya sastra. Berdasarkan hasil penelitian, dapat disimpulka bahwa realitas sosial dalam novel Lontara Rindu karya S. Gegge Mappangewa. Terdiri atas tiga realitas sosial yaitu realitas sosial tentang budaya, realitas sosial tentang pendidikan, dan realitas sosial tentang agama. Realitas sosial tentang budaya, meliputi kepercayaan, kebiasaan, adat istiadat kesenian, dan hukum adat. Realitas tentang pendidikan yaitu guru dan siswa, guru dan masyarakat. dan realitas tentang agama menggambarkan nilai-nilai ajaran agama dan niali-nilai cinta kepada Tuhan.
\end{abstract}

Kata Kunci; Novel; Realitas; Sosiologi Karya Sastra. 


\begin{abstract}
This research is motivated by the consideration that the novel Lontara Rindu by S. Gegge Mappangewa is very thick in presenting social realities that exist in society. The problem in this research is how is the social reality in the novel Lontara Rindu by S. Gegge Mappangewa ?. This study aims to describe the social reality contained in the novel Lontara Rindu by S. Gegge Mappangewa. The method used in this research is descriptive qualitative method. This research is a type of library research. The data in this study are written data in the form of novel texts which cover the social reality in the novel. the source of this research data is the Lontara Rindu novel by S. Gegge Mappangewa published by Republika, south Jakarta, the first printing in 2012 and consists of 343 pages. Data collection techniques used note-taking techniques. The data in this study were analyzed using the sociological approach to literary works. Based on the research results, it can be concluded that the social reality in the novel Lontara Rindu by S. Gegge Mappangewa. Consisting of three realitas social is the social reality of the culture, realitas social education, and realitas social about religion. Social reality about culture, including beliefs, habits, cultural customs, and customary law. The reality about education, that is, teachers and students, teachers and society, and the reality of religion illustrates the values of religious teachings and the values of love for God
\end{abstract}

Keywords; The novel ; Reality ; Sociology of Literary Works. 


\section{Pendahuluan}

Sastra menampilkan gambaran kehidupan, dan kehidupan itu sendiri merupakan kenyataan sosial yang tercermin dimasyarakat. Kehadiran karya sastra merupakan bagian dari kehidupan masyarakat tentu hal itu akan terbatas pada pengalaman dan daya hayal pengarang. Hal ini sependapat dengan (Wicaksono, 2014: 2) menyatakan bahwa karya sastra merupakan hasil kehidupan jiwa yang menjelma dalam tulisan atau bahasa tulis yang mencerminkan peristiwa kehidupan masyarakat.

Novel adalah sebuah hasil karya sastra yang mengemukakan sesuatu secara bebas, menyajikan sesuatu lebih banyak, lebih rinci, lebih detail dan lebih kompleks, serta menyampaikan permasalahan yang kompleks secara penuh, kreatif dan mengkritisi dalam dunia nyata. Menurut Plato (dalam Sumardjo, 1999: 18) sebuah novel tidak hanya mencerminkan realitas melainkan lebih dari itu memberikan kepada kita sebuah refleksi realitas yang lebih besar, lebih lengkap, lebih hidup, dan lebih dinamik yang melampaui pemahaman umum.

Realitas sosial adalah kenyataan yang dapat kita lihat dalam kehidupan manusia yang terwujud sebagai hasil hubungan yang terjalin di antara sesama manusia. Seperti halnya pendapat Bungin (dalam Wellek dan Werren, 2014: 218) mengatakan bahwa realitas itu "ada" dilihat dari subjektivitas "ada" itu sendiri dan dunia objektif di sekeliling realitas sosial itu. Individu tidak hanya dilihat sebagai kedirian-nya, namun juga dilihat dari mana "kedirian" itu hadir, bagaimana ia menerima dan mengaktualisasikan dirinya serta bagaimana pula lingkungan menerimanya.
Alasan peneliti memilih novel Lontara Rindu Karya S. Gengge Mappangewa sebagai objek kajian dalam penelitian ini karena mempunyai gagasan yang menarik untuk dikaji dan diteliti dengan beberapa alasan yaitu pertama, novel ini ditulis oleh $S$. Gengge Mappangewa yang merupakan satu di antara laki-laki yang berani mengangkat isu-isu tentang suara perempuan Bugis di Wilayah Sidenrreng Rappang, Sulawesi Selatan yang terbungkam akibat adanya kekakuan adat dan norma. Kedua, novel Lontara Rindu Karya S. Gengge Mappangewa mengambil tema pencitraan yang dekat dengan realitas sosial kehidupan masyarakat Bugis yaitu berawal dari perjuangan cinta sepasang kekasih yang terhalang akibat adanya perbedaan agama dan menimbulkan perceraian antara Haliamah dan Ilham. Dan sebelum itu ia telah dikaruniai anak bernama Vito dan Vino, yang terlahir sebagai saudara kembar. Mereka hidup dimana adat istiadat di sekeliling mereka sangat kental dengan kepercayaan Nenek moyang.

Salah satu alasan peneliti mengkaji realitas sosial dalam novel Lontara Rindu karya S. Gegge Mappangewa karena dalam novel ini menceritakan sebagian kehidupan di masyarakat. Kenyataan-kenyataan yang benar-benar terjadi dalam masyarakat dan saling berkaitan kehidupan seharihari para tokoh di dalamnya. Kelebihan dari novel ini terletak pada ceritanya yang menguraikan satu persatu tentang adat dan budaya Bugis Pangkep.

Oleh karena itu, untuk mengungkapkan realitas sosial yang ada dalam novel Lontara Rindu karya S. Gengge Mappangewa yakni dengan menggunakan pendekatan sosiologi karya sastra. pendekatan Sosiologi karya sastra merupakan salah satu alat yang tepat untuk digunakan dalam 
menganalisis isi dan bagian dari kehidupan masyarakat atau tokoh-tokoh yang ada dalam novel Lontara Rindu karya S. Gengge Mappangewa. Karena, sosiologi karya sastra adalah pendekatan yang mempermasalahkan tentang isi karya sastra, tujuan serta hal-hal lain yang tersirat dalam karya sastra itu sendiri dan berkaitan dengan masalah sosial apa tujuan atau amanat yang hendak disampaikan.

Berdasarkan latar belakang yang telah diuraikan, dapat dirumuskan masalah yakni bagaiamanakah realitas sosial dalam novel Lontara Rindu karya S Gegge Mappangewa.

Tujauan yang ingin dicapai dalam penelitian ini adalah untuk mendeskripsikan dan menganalisis realitas sosial yang terdapat di dalam novel Lontara Rindu karya S Gegge Mappangewa.

Adapun manfaat penelitian yang inigin dicapai dari hasil penelitian ini adalah sebagai berikut.

1. Memberikan pengalaman berfikir ilmiah melalui penyusunan dan penulisan skripsi, sehingga dapat menambah pengetahuan, pengalaman, dan menambah wawasan dalam bidang apresiasi sastra.

2. Sebagai bahan bacaan bagi pengajar dan pelajar dalam kaitannya dengan mata pelajaran Bahasa dan Sastra Indonesia utamanya karya sastra.

3. Dapat memberikan masukan pada perkembangan sastra khususnya dalam menganalisis realitas sosial dalam novel dengan menggunakan pendekatan sosiologi karya sastra.

Secara etimologis, kata sastra dalam bahasa Indonesia berasal dari bahasa Sansekerta, sastra. Dalam bahasa
Sansekerta, kata sastra dibentuk dari akar kata sas- dan -tra. Akar kata sas- (dalam kata kerja turunan) menunjukkan arti mengarahkan, mengajar, memberi petunjuk atau instruksi, sedangkan akar kata -tra menunjukkan arti alat atau sarana. Dengan demikian, sastra dapat berarti alat untuk mengajar, buku petunjuk, buku instruksi atau buku pengajaran (Sehandi, 2018: 2). Secara leksikal, sastra diartikan sebagai "bahasa (kata-kata, gaya bahasa) yang dipakai dalam kitab-kitab (bukan bahasa seharihari), kesustraan” KBBI (Sehandi, 2018: 3).

Sastra adalah lembaga sosial yang menggunakan bahasa sebagai medium, bahasa merupakan ciptaan sosial. Sastra menampilkan gambaran kehidupan dan kehidupan adalah suatu kenyataan sosial. Seluruh peristiwa yang terjadi dalam batin seseorang; yang sering menjadi bahan sastra adalah pantulan hubungan seseorang dengan orang lain atau masyarakat (Wicaksono, 2014: 12).

Sejak zaman Plato sastra digunakan untuk menjembatani anatar fakta dengan fiksi, anatara kenyataan dengan rekaan, Ratna (2008: 218). Menurut Plato (dalam Faruk, 2014: 47-48) dunia dalam karya sastra merupakan tiruan terhadap dunia kenyataan yang sebenarnya juga merupakan tiruan terhadap dunia ide. Dengan demikian, apabila dunia dalam karya sastra membentuk diri sebagai sebuah dunia sosial, dunia tersebut merupakan tiruan terhadap dunia sosial yang ada dalam kenyataan sebagaimana yang dipelajari oleh sosiologi.

Novel adalah cerita, dan cerita yang digemari manusia sejak kecil. Dan tiap hari manusia senang pada cerita, entah faktual, untuk gurauan, atau sekedar ilustrasi dalam percakapan. Bahasa novel juga bahasa denotatif, tingkat kepadatan dan makna gandanya 
sedikit. Jadi novel mudah dibaca dan dicernakan (Sumardjo, 1999 : 11).

Menurut Semi, Atar (dalam Wicaksono, 2014: 115) menyatakan bahwa novel mengungkapkan suatu konsentrasi kehidupan pada suatu saat tegang, dan pemusatan kehidupan yang tegas. Novel merupakan karya fiksi yang mengungkapkan aspek kemanusiaan yang mendalam dan disajikan dengan halus.

Berdasarkan beberapa pendapat di atas dapat disimpulkan bahwa novel adalah sebuah cerita yang diambil dari kehidupan dan perilaku yang nyata. Hal ini, serupa dengan pendapat Lukacs (dalam Yoesoef 2007: 8) sebuah novel tidak hanya mencerminkan realitas melainkan lebih dari itu memberikan kepada kita sebuah refleksi realitas yang lebih besar, lebih lengkap, lebih hidup, dan lebih dinamik yang melampaui pemahaman umum.

Sebuah novel merupakan sebuah totalitas, suatu kemenyeluruhan yang bersifat artistik. Sebagai sebuah totalitas, novel mempunyai bagian-bagian, unsurunsur, yang saling berkaitan satu dengan yang lain secara erat dan saling menggantungkan (Nurgiyantoro, 2013: 29). Unsur-unsur yang dimaksud adalah unsur intrinsik dan esktrinsik. Kedua unsur inilah yang sering banyak disebut para kritikus dalam rangka mengkaji dan atau membicarakan novel atau karya sastra pada umumnya (Nurgiyantoro, 2013: 29-30).

Unsur Intrinsik Meliputi:

1. Tema (Theme)

Menurut Stanton dan Kenny (dalam Nurgiyantoro, 2009: 67) tema (theme) adalah makna yang terkandung oleh sebuah cerita. Dilanjutkan oleh Hartoko dan Rahmanto (dalam Nurgiantoro, 2009: 68) tema merupakan gagasan dasar umum yang menopang sebuah karya sastra dan yang terkandung di dalam teks sebagai struktur semantis dan yang menyangkut persamaanpersamaan atau perbedaan-perbedaan.

2. Alur atau Plot

Secara umum, alur merupakan rangkaian peristiwa-peristiwa dalam sebuah cerita. Istilah alur biasanya terbatas pada peristiwa-peristiwa yang terhubung secara kausal saja. Peristiwa kausal merupakan peristiwa yang menyebabkan atau menjadi dampak dari berbagai peristiwa lain dan tidaak dapat diabaikan karena akan berpengaruh pada keseluruhan karya (Stanton, 2012: 26).

3. Latar (Setting)

Latar menurut Abrams (Nurgiyantoro, 2009: 216) latar atau setting yang disebut juga sebagai landas tumpu, menyaran pada pengertian tempat, hubungan waktu, dan lingkungan sosial tempat terjadinya peristiwa-peristiwa yang diceritakan. Stanton mengelompokkan latar, bersama dengan tokoh dan plot, ke dalam fakta (cerita) sebab ketiga hal inilah yang akan dihadapi, dan dapat diimajinasi oleh pembaca secara faktual jika membaca cerita fiksi.

4. Tokoh dan Penokohan

1.) Tokoh

Istilah "tokoh" menunjuk pada orangnya, pelaku cerita, misalnya sebagai jawab terhadap pertanyaan: "Siapakah tokoh utama novel itu?", atau "Ada berapa orang jumlah pelaku novel itu?", atau "Siapakah tokoh protagonis dan antagonis dalam novel itu?", dan sebagainya. Watak, perwatakan, dan karakter, menunjuk pada sifat dan sikap para tokoh seperti yang ditafsirkan pembaca, lebih menunju

2.) Penokohan

Penokohan dan karakterisasikarakterisasi sering juga di samakan artinya dengan karakter dan perwatakan menunjuk pada penempatan tokoh-tokoh tertentu dengan watak-watak tertentu 
dalam sebuah cerita (Nurgiantoro, 2009: 165). atau seperti dikatakan Jones (Nurgiantoro, 2009: 165) penokohan adalah pelukisan gambaran yang jelas tentang seseorang yang di tampilkan dalam sebuah cerita.

\section{Sudut Pandang (Point of View)}

Sudut pandang, point of view, view point, merupakan salah satu unsur fiksi yang oleh Staton digolongkan sebagai sarana cerita, literary device. Walau demikian, hal itu tidak berarti bahwa perannya dalam fiksi tidak penting. Sudut pandang haruslah diperhitungkan kehadirannya, bentuknya, sebab pemilihan sudut pandang akan berpengaruh terhadap penyajian cerita. Reaksi efektif pembaca terhadap sebuah cerita fiksi pun dalam banyak hal akan dipengaruhi oleh bentuk sudut pandang. (Nurgiyantoro, 2009: 246).

6. Gaya Bahasa

Nurgiyantoro (2009: 272) juga berpendapat bahwa bahasa dalam seni sastra dapat disamakan dengan cat dalam seni lukis. Keduanya merupakan unsur bahan, alat, dan sarana, yang diolah untuk dijadikan sebuah karya yang mengandung "nilai lebih" daripada sekedar bahannya itu sendiri. Bahasa merupakan sarana pengungkapan sastra.

Dapun unsur ekstrinsi ialah unsur yang membentuk karya sastra dari luar sastra itu sendiri. Untuk melakukan pendekatan terhadap unsur ektrinsik, diperlukan bantuan ilmu-ilmu kerabat seperti sosiologi, psikologi, filsafat, dan lain-lain, Redaksi PM (2012: 8).

Unsur ektrinsik (extrinsic) adalah unsur-unsur yang berada di luar teks sastra itu, tetapi secara tidak langsung memengaruhi bangun atau sistem organisme teks sastra. Atau, secara lebih khusus ia dapat dikatakan sebagai unsurunsur yang memengaruhi bangun cerita sebuah karya sastra, namun sendiri tidak ikut menjadi bagian di dalamnya. Walau demikian, unsur ektrinsik cukup berpengaruh (untuk tidak dikatakan: cukup menentukan) terhadap totalitas bangun cerita secara keseluruahan. Oleh karena itu unsur ektrinsik sebuah novel haruslah tetap dipandang sebagai sesuatu yang penting, Wellek dan Warren (dalam Nurgiyantoro, 2013: 30).

Sebagaimana halnya unsur intrinsik, unsur ektrinsik juga terdiri dari sejumlah unsur. Unsur-unsur yang dimaksud antara lain adalah keadaan subjektivitas individu pengarang yang meniliki sikap, keyakinan, dan pandangan hidup yang kesemuanya itu akan memengaruhi karya yang ditulisnya. Pendek kata, unsur biografi pengarang akan turut menentukan corak karya yang dihasilkannya. Unsur ekstrinsik berikutnya adalah psikologi, baik yang berupa psikologi pengarang (yang mencakup proses kreatifnya), psikologi pembaca, maupun penerapan prinsip psikologi dalam karya. Keadaan di lingkungan pengarang seperti ekonomi, politik, dan sosial juga akan berpengaruh terhadap karya sastra, dan hal itu merupakan unsur ekstrinsik pula. Unsur ekstrinsik yang lain misalnya pandangan hidup suatu bangsa, berbagai karya seni yang lain, dan sebagainya Wellek dan Warren (dalam Nurgiyantoro, 2013: 30-31) berpendapat bahwa

Menurut Winjosoebroto (dalam Marlina, 2017: 5) menyatakan realitas sosial dalam artinya sebagai sesuatu yang tampak dan sebenarnya adalah fakta, namun dalam maknanya yang tidak hanya sebaagai suatu (being) yang disadari, diketahui atau bahkan yang dipahami dan diyakini (realized) boleh dan ada di dalam pikiran manusia. Maka yang namanya realitas itu tak mesti berhenti pada konsep realitas sebagai realitas individual, melainkan realitas sosial yang menjadi bagian dari kesadaran, pengetahuan, atau keyakinan 
suatu kelompok kecil saja, malah mungkin hanya terdiri dari dua individu yang tengah berintegrasi saja.

Winjosoebroto (dalam Marlina, 2017: 5), megatakan adanya dua realitas sosial, yang pertama orang mengetahui realitas sebagai akibat dari pengalaman langsung orang tersebut dengan dunianya, sedangkan yang kedua sebagai akibat dari kabar (informasi) orang lain yang dia terima dan orang lain serta dirinya sendiripun turut mendukung suatu peristiwa yang memang benar terjadi di tengah-tengah masyarakat.

Adapun konsep-konsep realitas sosial, yakni:

1. Realitas Sosial Tentang Kebudayaan

Budaya adalah bentuk jamak dari kata budi dan daya yang berarti cipta, karsa, dan rasa. Kata budaya sebenarnya berasal dari kata sanskerta budhayah, yaitu bentuk jamak kata budi atau akal. Dengan demikian sejalan dengan pendapat Taylor (dalam Wicaksono, 2014: 325). Budaya adalah suatu keseluruhan konpleks yang meliputi pengetahuan, kepercayaan, kesenian, moral, keilmuan, hukum adat, adat istiadat dan kemampuan yang lain serta kebiasaan yang didapat oleh manusia sebagai anggota masyarakat.

2.Realitas Sosial Tentang Pendidikan

Pendidikan adalah suatu usaha manusia untuk mencapai tujuan hidupnya yang dilakukan terus-menerus dan dimulai sejak anak dilahirkan sampai ia meninggal dunia 'long life education' (Wicaksono, 2014: 300).

Pendidikan berlangsung seumur hidup. Pendidikan adalah tuntunan dalam hidup tumbuhnya anak-anak, maksudnya yaitu menuntun segala kekuatan kodrat yang ada pada anakanak itu agar mereka sebagai manusia dan sebagai anggota masyarakat dapat mencapai keselamatan dan setinggi- tingginya Dewantara, Ki Hadjar (dalam Wicaksono, 2014: 300).

3. Realitas Sosial Tentang Agama

Menurut (Nottingham, 1985: 3) agama adalah gejalah yang begitu sering "terdapat di mana-mana", dan agama berkaitan dengan usaha-usaha manusia untuk mengukur dalamnya makna dari keberadaan diri sendiri dan keberadaan alam semesta selain itu agama dapat membangkitkan kebahagiaan batin yang paling sempurna. Meskipun perhatian tertuju kepada adanya suatu dunia yang dapat dilihat (akhirat), namun agama melibatkan dirinya dalam masalahmasalah kehidupan sehari-hari di dunia.

Agama dalam kehidupan berfungsi sebagai sauatu sistem nilai yang memuat nilai yang memuat normanorma moral tertentu. Secara umum norma-norma moral tersebut menjadi kerangka acuan dalam bersikap dan bertingkah laku agar sejalan dengan keyakinan agama yang dianutnya. Sebagai sistem nilai agama memiliki arti yang khusus dalm kehidupan serta dapat dipertahankan sebagai bentuk ciri khas.

4. Pendekatan Sosiologi Karya Sastra

$$
\text { Menurut Wellek (dalam }
$$

Wicaksono, 2014: 44) membagi telaah sosiologi menjadi tiga klasifikasi yaitu:

a. Sosiologi pengarang, profesi pengarang dan istitusi sastra, masalah yang berkaitan di sini adalah dasar ekonomi produksi sastra, latar belakang sosial, status pengarang, dan ideologi pengarang yang terlihat dari berbagai kegiatan pengarang di luar karya sastra.

b. Sosiologi karya, yakni mempermasalahkan tentang isi karya sastra, tujuan serta hal-hal lain yang tersirat dalam karya sastra itu sendiri dan berkaitan dengan masalah sosial dan apa tujuan atau amanat yang hendak disampaikan. 
c. Sosiologi sastra yang mempermasalahnkan pembaca dan dampak sosial karya sastra. Sejauh mana sastra ditentukan atau tergantung dari latar sosial, perubahan, dan perkembangan sosial adalah pertanyaan yang termaksud dalam ketiga jenis permasalahan di atas: sosiologi pengarang, isi karya sastra yang bersifat sosial, dan dampak sastra terhadap masyarakat.

Metode yang digunakan dalam penelitian ini adalah metode deskriptif kualitatif. Metode deskriptif kualitatif digunakan untuk mendeskripsikan data menginterpretasi data-data tertulis yang berupa realitas sosial dalam novel Lontara Rindu karya S. Gengge Mappangewa, metode deskrptif digunakan untuk untuk menggambarkan data-data berdasarkan kenyataan yang ada dalam novel Lontara Rindu karya S. Gengge Mappangewa, kualitatif dalam menjelaskan konsepkonsep yang berkaitan satu sama lain menggunakan kata-kata jadi penelitian ini bukan berbentuk angka-angka melainkan deskripsi bahasa.

Penelitian ini adalah penelitian kepustakaan. Dikatakan penelitian kepustakaan karena data penelitian ini didukung oleh buku-buku referensi dan memanfaatkan sumber kepustakaan untuk memperoleh data penelitian terkait dengan masalah yang diambil.

Data yang digunakan dalam penelitian ini adalah data tertulis berupa teks novel yang mencangkup realitas sosial yang terdapat dalam novel Lontara Rindu karya S. Gengge Mappangewa.

Adapun sumber data utama dalam penelitian ini adalah novel Lontara Rindu karya S. Gengge Mappangewa, terbitkan Republika, Jakarta Selatan. cetakan pertama, tahun 2012 dan terdiri dari 342 halaman.

Teknik pengumpulan data yang digunakan dalam penelitian ini adalah teknik baca catat. Teknik baca yaitu suatu teknik yang dilakukan peneliti dengan membaca secara berulang-ulang dengan teliti pada novel Lontara Rindu karya S. Gengge Mappangewa sebagai objek penelitian. Teknik catat yaitu mencatat data-data yang diperoleh dari isi novel sesuai dengan masalah penelitian yakni tentang bagaimana realitas sosial dalam novel/karya itu sendiri.

Data dalam penelitian ini dianalisis berdasarkan bentuk masalah realitas sosial dalam novel Lontara Rindu karya S. Gengge Mappangewa dengan menggunakan pendekatan sosiologi karya sastra, pendekatan sosiologi karya sastra yakni mempermasalahkan tentang isi karya sastra, tujuan, serta hal-hal lain yang tersirat dalam karya sastra itu sendiri, dan berkaitan dengan masalah sosial serta tujuan dan amanat yang hendak di sampaikan, Wellek (dalam Wicaksono, 2014: 44). Untuk memahami lebih dalam lagi gejala sosial yang terkandung dalam novel Lontara Rindu karya S. Gengge Mappangewa dengan cara peneliti mendeskripsikan atau menggambarkan realitas sosial.

Selengkapnya teknik analisis data yang dimaksud akan dilakukan dengan tahapan berikut:

a. Identifikasi data, maksudnya data realitas sosial yang sudah diberi kode sesuai dengan permasalahn penelitian.

b. Klasifikasi data, yaitu mengklasifikasi data berdasarkan jenis realitas sosial dalam novel.

c. Deskripsi data yaitu, gambaran data realitas sosial yang telah ditafsirkan kedalam bentuk paparan pembahasan.

d. Analisis data, yaitu menganalisis data realitas sosial dengan metode yang sudah ditentukan.

e. Interpretasi data, yaitu memberikan gambaran secara umum tentang hasil penelitian yang diperoleh, hal tersebut 
tampak pada simpulan hasil penelitian.

\section{Pembahasan}

Gambaran Umum Novel Lontara Rindu Karya S. Gegge Mappangewa sebagai berikut:

1. Alur

Alur cerita dalam novel Lontara Rindu karya S. Gegge Mappangewa ini menggunakan alur campuran di mana pengarang menuliskan cerita secara berurutan, dan selanjutnya menyisipkan kembali cerita di masa lalu.

2. Latar

Latar cerita dan tempat paling pokok diambil dalam cerita novel Lontara Rindu karya S. Gegge Mappangewa ini adalah di daerah Sidrap (Sidenreng Rappang) Sulawesi Selatan. S. Gegge Mappangewa memilih Provinsi Sulawesi Selatan sebagai tempat dimana cerita berada, dilatar belakangi oleh kelahiran Sang Penulis sendiri yaitu di Sulawesi Selatan. dari hal itu Sang Penulis sangat lincah dan hafal setiap nama tempat yang tertulis dengan penggambaran keadaan yang sama dengan aslinya yaitu rumah, kebun, sekolah, dan nama kota terjadinya peristiwa. Dan Penulis berhasil memadupadankan semuanya dengan serasi tentang konflik yang sering terjadi di dalam kehidupan masyarakat. juga menyampaikan adat istiadat serta ritual dan juga kepercayaan orang Bugis di novel ini.

\section{Tokoh}

Adapun tokoh-tokoh yang terdapat dalam novel Lontara Rindu karya S. Gegge Mappangewa adalah Vito dan Vino (saudara kembar), Halima (Ibu Vito dan Vino), Ilham (Ayah Vito dan Vino), Maulidah (guru ips), Amin (guru penjas), Sivinta (guru mate-matika), Bahktiar (kepala sekolah), Aziz (sepupu Halima), Beddu (pedagang kerbau), dan sahabatsahabat Vito yaitu Irfan (ketua kelas),
Alif, Bimo, Waddah, Azis, Sarah, dan Anugerah.

Gambaran dari cerita yang disuguhkan dalam novel Lontara Rindu ini, benar-benar bisa membuat kita mengartikan, bahwa tidak semua kisah hidup harus bahagia seperti kisah Cinderella. Kebahagiaan itu sendiri bersifat relatif, artinya setiap orang bisa saja mempunyai pemahaman yang berbeda terhadap makna bahagia. Hal itu mengajarkan manusia bahwa segala sesuatu dalam hidup ini membutuhkan pengorbanan, termasuk cinta, keluarga dan keyakinan. Kebahagiaan itu sendiri berkumpul dalam akhir yang bisa dimaknai dengan hikmah. Pertemuan adalah obat kerinduan. Dari situ bisa diartikan, bahwa kebahagiaan ada dalam pertemuan itu walaupun ada beberapa keadaan yang tak sesaui dengan harapan dan keinginan. Itulah realitas, bisa saja memang hampir semua tak sama seperti gambaran manusia. Di dalam novel ini sendiri, selama berjalnnya alur di setiap kejadian, selalu ada hikmah dan pelajaran yang bisa diambil. Melalui rindu yang berderu itu Vito membuka tragedi masa lalu yang menimpa ibunya. Mengapa ia dan ibunya harus berpisah dengan ayahnya dan saudara kembarnya Vino. Selain itu, tanpa sadar, Vito juga telah menyibak fakta di balik keberadaan penganut keyakinan Tolotang di antara masyarakat Muslim Bugis. Kerinduan Vito yang tulus, dapat dikatakan adalah pelita penerang bagi sepenggal riwayat kehidupan keluarganya yang disembunyikan oleh ibunya dan kakenya sendiri.

Kehidupan masyarakat sebagai makhluk sosial yang pada dasarnya berupaya untuk mempertahankan hidup menuju ke kehidupan yang lebih baik, masyarakat sebagai makhluk sosial tidak dapat berdiri sendiri tanpa bantuan dan kerjasama dengan orang lain di dalam 
bermasyarakat. Pengetahuan yang demikian kemudian melahirkan kesadaran bahwa setiap masyarakat terpanggil hatinya untuk melakukan apa yang terbaik bagi masyarakatnya. Semangat itu secara tidak langsung telah menumbuhkan sikap dasar bahwa untuk mewujudkan keselarasan, keserasian, dan keseimbangan dalam hubungan sosial antarmanusia, pribadi, dan masyarakatnya perlu adanya pemahaman mendalam mengenai aspekaspek filosofis nilai budaya, pendidikan, dan agama sebagai bagian dari bentukan masyarakat dalam tatanan norma bermasyarakat.

Novel Lontara Rindu mengangkat kisah problematika realitas sosial kehidupan masyarakat Bugis dari berbagai macam segi. Perwatakan tokoh dan rangkaian peristiwa secara tidak langsung menyinggung atau melihat realitas keidupan sosial budaya-budaya Bugis dalam pembagian- ceritanya. Untuk lebih jelasnya melalui hasil analisis ini peneliti akan bisa membuktikan bahwa karya sastra bukan sekedar bualan belaka pengarang. Namun, dibalik imajinasi ini pengarang membubuhkan makna ideologis. Adapun berdasarkan hasil analisis, realitas sosial dalam novel Lontara Rindu karya S. Gegge Mappangewa terfokus pada realitas tentang kebudayaan, realitas tentang pendidikan dan realitas tentang agama, yang menjadi hasil dari analisis peneliti sendiri. Adapun bentuk realitas yang dimaksud adalah sebagai berikut.

\section{A. Realitas Sosial Tentang Kebudayaan} dalam Novel Lontara Rindu Karya S. Gegge Mappangewa

Budaya adalah suatu keseluruhan yang konpleks meliputi pengetahuan, kepercayaan, kesenian, moral, keilmuan, hukum adat, adat istiadat dan kemampuan yang lain serta kebiasaan yang didapat oleh manusia sebagai anggota masyaakat Taylor (dalam Wicaksono, 2014:325).

Adapun realita sosial tentang kebudayaan yang terkandung dalam novel Lontara Rindu Karya S. Gegge Mappangewa sebagai berikut:

1. Kepercayaan Suku Bugis dalam Novel Lontara Rindu Karya S. Gegge Mappangewa.

"Menurut kepercayaan orang-orang Bugis, orang yang punya keluarga atau kerabat sebagai manusia reptil tak akan pernah meniggal akibat tenggelam, hanyut, atau meniggal dengan cara apa pun di dalam air. Sebagaian orang mempercayai manusia reptil sering ke kaki bendungan, yang di sana juga ada beringin raksasa, untuk membawa sesajen. Sesajen itu biasanya dibawa sebelum atau sesudah melaksanakan hajatan, seperti pernikahan atau bahkan mungkin wisuda." (Mappangewa, 2012: 6).

Kutipan tersebut di atas, memberikan penegasan bahwa realitas tentang kepercayaan orang-orang Bugis mengenai manusia yang berkembarkan hewan tumbuh dan hidup bersama mereka dalam setiap aktivitas sosial kemasyarakatan. Ini terlihat dalam kutipan diatas bahwa masyarakat Bugis, pergi membawa sesajen untuk hewan kembaran baik sebelum atau sesudah hajatan. Sikap dan perilaku ini mengandung makna historis bahwa antara hewan reptil sebagai kembaran manusia memiliki hubungan naluriah dengan manusia kerabat keluarga yang berkembaran hewan tersebut. Mengapa kerena pada sisi lain, dengan adanya kepercayaan bahwa ada orang-orang tertentu yang berkembarkan dengan hewan, secara tidak sadar telah menumbukan atau melahirkan suatu sugesti kepada diri bahwa merekamereka yang termasuk dalam kerabat 
orang yang memiliki kembaran dengan hewan tadi tidak akan dapat meniggal di dalam air, baik itu tenggelam maupun hanyut. Melalui kepercayaan itulah, jiwa berani menantang badai lautan menjadi hal realitas sosial yang tidak membuat kendur semangat melaut orang-orang Bugis. Hingga dalam sejarahnya orangorang Bugis ini terkenal sebagai pelaut ulang yang handal dalam mengarungi samudra tanpa mengenal lelah dan takut.

2. Kebiasaan Suku Bugis dalam Novel Lontara Rindu Karya S. Gengge

Mappangewa.

"Tak ada undangan khusus untuk kegiatan-kegiatan seperti itu. Warga hanya perlu tahu kapan acara pernikahannya. Jika itu sudah diketahui, maka telah menjadi tradisi, mulai dari H-7 keluarga dan tetangga akan datang membantu menggiling gabah dan maggoreng kopi (menggoreng kopi), lalu besoknya datang mattapi were' (membersihkan beras), besoknya lagi datang membuat kuwe kering, hingga nanti tiba di H-1, acara makkire'kire' (mengiris-iris daging hewan sembelihan yang akan dipakai dipesta). (Mappangewa, 2012: 45).

Kutipan di atas menjelaskan bahwa setiap memulai acara pernikahan biasanya suku Bugis yang ada di perkampungan selalu melakukan ke tiga hal ini, yang pertama sebelum mereka membuat acara biasanya orang-orang tua yang telah dipercaya pergi ke setiap rumah untuk memberi tahu atau mappada dalam bahasa Bugisnya, bahwa keluarga tersebut ingin mengadakan sebuah pernikahan, kedua setelah mereka mengetahui acara tersebut mereka datang untuk membantu menggiling beras, mengiris daging dan menapis beras tanpa adanya bayaran yang dikeluarkan.
3. Adat Istiadat Suku Bugis dalam Novel Lontara Rindu Karya S. Gegge Mappangewa.

"Sarapo telah berdiri. Keluarga dari segala penjuru telah berkumpul. Walasoji telah terisi: Kelapa perlambang keutuhan rumah tangga, tebu simbol manisnya cinta, nangka sebagai harap agar kasi sayang itu selalu besar. Semua telah siap! Belasan bunga desa dengan baju bodo siap membawa bosara. Pemuda pun tak kalah gagahnya dengan balutan jas tertutup dan songkok to Bone siap mengangkatwalasoji." (Mappangewa, 2012: 174).

Kutipan di atas menjelaskan tentang panggung yang didirikan di samping rumah sebagai tempat berkumpul saat pernikahan dan buahbuahan yang akan di bawa ketika Azis hendak mendatangi rumah Halimah untuk dinikahkan. Buah-buah di atas mempunyai arti masing-masing dalam suku Bugis. Termaksud pakaian yang digunakan pemuda. Walasuji merupakan tempat buah-buahanan dibawah ke rumah perempuan pada saat akad nikah akan dilaksanakan dan bosara adalah sebuah wadah atau tempat yang digunakan untuk menyajikan kue. Namun jika membawanya ke mempelai wanita bosara tersebut di isi dengan berbagai macam peralatan wanita. Misalnya seperti sandal, sarung, cincin, bedak dan perlengkapan lainnya.

4. Kesenian Suku Bugis dalam Novel Lontara Rindu Karya S. Gegge Mappangewa.

“Beberapa rumah panggung orangorang Bugis bahkan memiliki tang belakang, agar saat ada tamu sementara makanan dan minuman yang akan dijamukan untuk tamu baru mau beli, maka harus lewat tangga belakang. Sang tamu tak boleh tahu kalau tuan rumah kehabisan 
gula pasir untuk ngopi atau apapaun yang akan dijamukan untuknya."(Mappangewa, 2012: 139)

Kutipan di atas menjelaskan bahwa rumah orang Bugis ditandai dengan rumah panggung mempunyai dua tangga depan dan belakang. Tak bisa di pungkiri dimanapun mereka tinggal pasti dominan rumahnya mempunyai tangga. Ketika orang-orang melihat rumah panggung dan mempunyai tangga depan dan belakang pasti mereka akan menyebut bahwa rumah itu adalah rumah suku Bugis. Realitas seperti sering terjadi dan bahkan ketika mereka merantau pasti selalu membangun rumah yang mempunyai tangga. Tapi seiring perkembangan zaman, orang-orang Bugis sudah banyak yang merubah nilai-nilai kebudayaan. Mereka tidak lagi membudayakan rumah adat sebagai simbol dirinya.

5. Hukum Adat Suku Bugis dalam Novel Lontara Rindu Karya S. Gegge Mappangewa.

"Ketika semua orang telah terlelap semalam. Ketika ayah dan ibunya yang telah yakin mampu menaklukkan hati Halimah untuk tunduk dinikahkan dengan Azis, tengah tersenyum dalam mimpi, Halimah melangkah diam-diam. Jinjit pelan-pelan, agar lantai papan yang diinjaknya tidak membangunkan tamu-tamu yang tidur melantai di luar kamar. Tamu-tanu itu tak lain adalah keluarga yang datang dari jauh. Seharian telah bekerja di dapur, kini tertidur pulas meskipun hanya beralaskan sarung dan bantal lengan." (Mappangewa, 2012: 177).

Kutipan di atas menjelaskan bahwa Halimah tak mau di dipersunting oleh Azis, ia lebih memilih kabur dari rumah untuk menemui kekasihnya Ilham daripada harus duduk bersanding dengan Azis orang yang tak dicintainya. Halimah diam-diam melangkahkan kaki untuk keluar rumah dan pergi mencari Ilham meskipun nyawa taruhannya.

\section{B. Realitas Tentang Pendidikan}

Realitas sosial tentang pendidikan sangat beriorentasi terhadap kebutuhan serta sistem pendidikan dalam masyarakat. pendidikan pada hakikatnya suatu kegiatan yang secara sadar dan sengaja, serta penuh tanggungjawab yang dilakukan oleh orang dewasa kepada anak-anak sehingga timbul interaksi dari keduanya agar anak tersebut mencapai kedewasaan yang di cita-citakan dan belangsung terus-menerus dan Pendidikan sangat berperan terhadap setiap individu-individu manusia. Sebab, dengan adanya pendidikan pengetahuan setiap manusia dapat meningkat (Wicaksono, 2014: 300).

Adapun realita sosial tentang pendidikan yang terkandung dalam novel Lontara Rindu Karya S. Gegge Mappangewa sebagai berikut:

1. Hubungan Guru dan Siswa

"Seisi kelas hanya mampu menjawab salam dalam hati. Bu Maulindah baru sadar kalau dia belum mengabsen siswanya, dan ternyata Vito lagi-lagi terlambat hari ini. Padahal rumahnya hanya sepelemparan lembing dari sekolah. Bel sekolah pun kedengaran di rumahnya. Kedatangannya selal u dengan napas tersengal. Sepertinya dia cocok untuk jadi pelari maraton. Hampir tiap hari berlomba lari dengan Bu Maulindah. Dia lari dari rumah ke sekolah, sementara $\mathrm{Bu}$ Maulindah dari kantor ke kelas. Meski Bu Maulindah hanya berjalan, tetaplah Vito selalu terlambat." (Mappangewa, 2012: 14). 
Kutipan di atas menggambarkan realitas sosial. Dimana siswa-siswa sering kita jumpai terlambat masuk sekolah. Seperti realitas teks di atas bahwa Vito selalu saja terlambat masuk sekolah sebab rumahnya berada di samping sekolah. Ia sengaja mengunlur-unlur waktu untuk masuk kelas. Setiap harinya ia selalu berlari dari rumah hingga ke sekolah.

2. Hubungan Guru dan Masyarakat

Begitu apel bubar, Pak Bakhtiar, sang kepsek, yang rasa penasarannya tinggi, berlari mlihat kerumunan orang yang di tengah-tengahnya ada kerbau yang kepalanya siap menyerunduk. Sebagai seorang pemimpin Pramuka tertinggi di sekolah, Pak Bakhtiar member kode kepada Pak Amin untuk segera mendekat. Tapi bukan hanya Pak Amin, seluruh siswa ikut berlari untuk menyaksikan kejadian apa gerangan yang membuat orang berkumpul di sana" (Mappangewa 2012: 32).

"Pak, jangan-jangan kerbaunya berat meninggalkan Pak Beddu. Cobalah kamu yang bicara!" (Mappangewa, 2012: 33).

"saya tahu kamu tidak bisa berkomunikasi dengan kerbau seperti saya, tapi cobalah dengan bahasamu sendiri. Bahasa Indonesia boleh, bahasa Bugispun boleh. Hewan mengerti segala bahasa". (Mappangewa, 2012: 34).

Kutipan di atas menggambarkan realitas sosial. Ketika kepala sekolah mendengar ada kejadian di luar sekolah ia langsung berlari bersama siswanya dan ikut membantu masyarakat yang kesusahan menaikkan kerbau ke atas mobil dengan memberi dia syarat agar kerbaunya bisa naik ke atas truk. Kepala Sekolah adalah orang yang ahli dalam kepramukaan jadi hal- hal yang sulit seperti dalam hal ikat mengikat menjinakkan hewan ia sudah mengetahuinya. Itulah sebabnya ia menyuruh pemiliknya untuk berbahasa kepada kerbau dan menyuruhnya naik ke truk.

3. Realitas Tentang Agama

Menurut (Nottingham, 1985: 3) agama adalah gejalah yang begitu sering "terdapat di mana-mana", dan agama berkaitan dengan usaha-usaha manusia untuk mengukur dalamnya makna dari keberadaan diri sendiri dan keberadaan alam semesta selain itu agama dapat membangkitkan kebahagiaan batin yang paling sempurna. Meskipun perhatian tertuju kepada adanya suatu dunia yang dapat dilihat (akhirat), namun agama melibatkan dirinya dalam masalahmasalah kehidupan sehari-hari di dunia.

Agama dalam kehidupan berfungsi sebagai sauatu sistem nilai yang memuat nilai yang memuat normanorma moral tertentu. Secara umum norma-norma moral tersebut menjadi kerangka acuan dalam bersikap dan bertingkah laku agar sejalan dengan keyakinan agama yang dianutnya. Sebagai sistem nilai agama memiliki arti yang khusus dalm kehidupan serta dapat dipertahankan sebagai bentuk ciri khas. Agama sebagai bentuk keyakinan manusia terhadap sesuatu yang bersifat adikodrat (supernatural) ternyata seakan menyertai manusia dalam ruang lingkup kehidupan yang luas. Agama memiliki nilai-nilai bagi kehidupan manusia sebagai orang per orang maupun dalam hubungannya dengan kehidupan bermasyarakat. Selain itu agama juga memberi dampak bagi kehidupan seharihari. Dengan demikian, agama dapat berfungsi (dalam diri) dan motif ekstrinsik (luar diri). Dan motif yang didorong keyakinan agama dinilai memiliki kekuatan yang mengagumkan dan sulit ditandingi oleh keyakinan 
nonagama, baik doktrin maupu ideologi yang bersifat profan.

"kalaupun dia benar-benar mencintaimu, lalu dia benar-benar datang melamarmu, jangan harap saya akan menerima lamaran itu. Saya tidak sudi bermenantukan orang yang tak tahu posisi pintu masjid." (Mappangewa, 2012: 88).

Kutipan ucapan ayah Halimah tersebut diatas menggambarkan bahwa begitu tinggi dan sakralnya nilai-nilai ajaran agama dalam sebuah keluarga suku Bugis. Karena agama yang sangat berperan sebagai pedoman hidup dan tuntunan hidup menjadi tolak ukur yang sangat penting untuk diperhatikan khususnya dalam pernyatuan ikatan keluaraga dalam hal ini ikatan pernikahan. Pengetahuan dan pemahaman agama merupakan salah satu langkah yang dapat ditempuh oleh masyarakat atau suku Bugis dalam menjaga nama baik kelurganya. Dengan pemahaman yang baik akan membuat kedudukan keluarga Bugis menjadi semakin dihormati dan dihargai oleh masyarakat yang lain. Akan tetapi bila pemahaman akan pengetahuan agama dalam salah satu keluarga tidak ada maka hal itu akan menimbulkan aib dan rasa malu bagi mereka khususnya dalam lingkungan pergaulan.

Relevansi Hasil Penelitian dengan Pengajaran Sastra di Sekolah bahwa karya sastra yang baik adalah karya sastra yang dapat membekali siswa dengan ilmu yang bermanfaat bagi kehidupannya. Karya sastra yang baik dapat merubah pola pikir individu setelah membaca, menelaah karya sastra itu secara saksama. Karya sastra dikatakan menarik karena di dalamnya terkandung kenikmatan yang dapat menghibur siswa ketika membacanya khususnya novel.
Pembelajaran sastra di sekolah sangatlah penting karena karya sastra adalah wahana yang digunakan oleh pengarang untuk menentukan ide, gagasan, dan berbagai pikiran yang konstruktif. Karya sastra yang dijadikan sebagai bahan materi pelajaran di harapkan mengandung nilai positif yang dapat mengembangkan kepribadian dan kemampuan siswa. Pada prinsipnya tujuan pembelajaran sastra yang di sajikan kepada para siswa harus sesuai dengan kemampuannya pada suatu tahapan tertentu. Tujuan pembelajaran itu sendiri adalah menuntut peserta didik agar dapat memahami, menangkap makna, dan dapat mengambil hal-hal positif pada suatu karya sastra yang di ajarkan.

Pada silabus kurikulum 2018 hasil revisi, pada materi pelajaran Bahasa Indonesia kelas XI SMA terdapat materi KD (kompetensi dasar) 3.20 menganalisis pesan dari dua buku fiksi (novel dan buku kumpulan puisi) yang dibaca. KD tersebut menjadikan novel sebagai objek penelitiannya. Dengan adanya peneltian ini, peserta didik dapat menjadikan hasil penelitian sebagai contoh dalam menguraikan temuan- temuan dan informasi yang didapatkan dari dalam novel. Selain itu, dari hasil penelitian ini juga mendapatkan contoh tentang mengutip dari dalam teks novel untuk dijadikan sebagai bukti dari uraianuraian yang dipaparkan tentang sebuah temuan atau informasi.

Berangkat dari hal di atas, pembelajaran sastra adalah bagian yang tidak dapat terpisahkan dari kurikulum di sekolah, baik dijenjang pendidikan dasar, menengah, maupun diperguruan tinggi. Pembelajaran sastra di sekolah juga merupakan bagian dari mata pelajaran bahasa Indonesia. Tujuan penyajian sastra dalam dunia pendidikan adalah untuk memperoleh 
pengalaman dan pengetahuan tentang sastra, sehingga peserta didik memiliki apresiasi terhadap karya sastra. Salah satu upaya untuk meningkatkan daya apresiasi siswa terhadap karya sastra adalah dengan menghadapkan siswa secara langsung pada bentuk-bentuk karya sastra, misalnya pada novel. Novel merupakan salah satu bagian dari pembelajaran sastra dalam pelajaran bahasa Indonesia khususnya di sekolah menengah atas (SMA). Oleh karena itu, hasil penelitian ini layak digunakan sebagai bahan ajar di sekolah.

\section{Kesimpulan}

Berdasarkan analisis terhadap objek kajian dengan mencermati realitas sosial dalam novel Lontara Rindu karya S. Gegge Mappangewa menggunakan pendekatan sosiologi karya sastra, dapat ditarik kesimpulan bahwa realitas sosial dalam novel Lontara Rindu karya S. Gegge dideskripsikan dengan tiga realitas sosial yaitu realitas sosial budaya, realitas sosial pendidikan dan realitas sosial agama. . Pertama, realitas sosial tentang budaya, meliputi kepercayaan, kebiasaan, adat istiadat kesenian, dan hukum adat. Adapun realitas sosial tentang budaya kepercayaan yaitu kepercayaan tentang manusia yang mempunyai kembaran hewan reptil, kepercayaan tentang mantra dan pemali, Realitas sosial tentang budaya kebiasaan yaitu mappada (memberitahu ibu-ibu untuk datang membantu di acara pernikahan yang akan dibuat), mappalili (tradisi membajak sawah ketika memulai menanam), menjamu tamu dan perjodohan, Realitas sosial tentang budaya adat istiadat yaitu uang panai (uang yang diberikan mempelai pria untuk mempelai wanita), mappettu ada (menentukan hari akad nikah), sarapo (tenda untuk pesta pernikahan), dui papenre atau uang panai (uang belanja untuk kemeriahan pesta pernkahan) walasuji (buah yang akan dibawa ketika mendatangi mempelai wanita), Realitas sosial tentang budaya kesenian yaitu tentang bentuk rumah adat Bugis, Realitas sosial tentang hukum adat istiadat yaitu siri' (mempermalukan keluarga). Kedua realitas sosial tentang pendidikan meliputi hubungan guru dan siswa yaitu Pak Amin dan kedelapan siswanya dan Ibu Maulinda dan irfan. dan meliputi hubungan guru dan masyarakat yaitu Pak Amin dan kakek Vito, Pak Amin dan Pak Japareng, Kepala Sekolah dan masyarakat lainnya. Ketiga Realitas sosial tentang agama menggambarkan nilai-nilai ajaran agama dan niali-nilai cinta kepada Tuhan.

Penelitian ini hanya menitikberatkan pada sebuah analisis tentang realitas sosial dalam novel Lontara Rindu karya S. Gegge Mappangewa dengan menggunakan pendekatan sosilogogi karya sastra. Adapun saran yang dapat penulis kemukakan yaitu peneliti hanya mengkaji realitas sosial tentang budaya, pendidikan dan agama. Harapan kedepannya untuk peneliti selanjutnya dapat menelaah dan menganalisis kemabali novel tersebut dengan meneliti unsur-unsur yang ada di dalamnya dengan menggunakan pendekata-pendekatan sastra yang lain.

\section{Referensi}

Faruk. 2014. Pengantar Sosiologi Sastra. Yoyakarta: Pustaka Belajar.

Hendy, Zaidan. 1991. Pelajaran Sastra 1. Jakarta: PT Gramedia Widiasarana Indonesia.

Jabrohim. 2015. Teori Penelitian Sastra. Yogyakarta: Pustaka Pelajar.

Marlina, 2017. Realitas Sosial Kehidupan Tokoh Utama Dalam Novel Toba Dreams Karya TB Silalahi. Jurnal Bastra. Vol. 1 No. 4, Maret 
2017/2394-6568-1.

http://ojs.uho.ac.id/index.php/BAS

TRA/article/view/2394/1742.

Di akses pada tanggal 9 Desember 2019.

Mappangewa, S. Gegge. 2012. Lontara Rindu. Harian Republika. Jakarta Selatan.

Nurgiyantoro, Burhan. 2009. Teori Pengkajian Fiksi. Yogyakarta: Gadjah Mada University Press.

Nurgiyantoro, Burhan. 2013. Teori Pengkajian Fiksi. Yogyakarta: Gadjah Mada University Press.

Nottingham, K, Elizabeth. 1996. Suatu Pengantar Sosiologi Agama. Jakarta: PT Raja Grafindo Persada.

Ratna, Kutha Nyoman. 2008. Teori, Metode, dan Teknik Penelitian Sastra. Celeban Timur Yogyakarta: Pustaka Pelajar.

Redaksi PM. 2012. Sastra Indonesia Paling Lengkap. Jawa Barat: Pustaka Makmur.

Sehandi, Yohanes. 2018. Mengenal 25 Teori Sastra. Yogyakarta: Ombak.

Siswanto, Wahyudi. 2013. Pengantar Teori Sastra. Yogyakarta: Aditya Media Publishing.

Stanton, Robert. 2012. Teori Pengkajian Fiksi. Yogyakarta: Pustaka Pelajar.

Sumardjo, Jakob. 1999. Konteks Sosial Novel Indonesia 1920 - 1977. Bandung: Alumni.

Wellek, Rene dan Warren Austin. 2014. Teori Kesustraan. IKAPI Jakarta: Gramedia.

Wicaksono, Andri. 2014. Pengkajian Prosa Fiksi. Yogyakarta: Garudhawaca.

Yoesoef. 2007. Sastra dan Kekuasaan. Jakarta Selatan: Wedatama Widya Sasta. 